Prace Polonistyczne, seria LXXII, 2017

ISSN: 0079-4791; e-ISSN: 2450-9353

DOI: $10.26485 / \mathrm{PP} / 2017 / 72 / 1$

Marzena Karwowska

\title{
OBRAZY AKULTURACJI W „TAROCIE PARYSKIM”
}

\section{SŁOWA KLUCZOWE}

Manuela Gretkowska; Tarot paryski; akulturacja

Współczesny stan badań poświęconych akulturacji wskazuje, że jest to zagadnienie budzące $\mathrm{w}$ ostatnich latach coraz większe zainteresowanie naukowców (Rudmin 2003: 3-37, Berry 2006: 27-43, Berry 2003: 17-37, Kim, Abreu 2001: 394-424, Malewska-Peyre 2001). W latach trzydziestych dwudziestego wieku, za sprawą antropologów (Roberta Redfielda, Ralpha Lintona i Melville’a Herskovitsa) krystalizuje się i zostaje wprowadzone do dyskursu humanistycznego rozumienie fenomenu akulturacji ${ }^{1}$, definiowanej jako zespół zjawisk, które pojawiają się wówczas, gdy grupy jednostek z rożnych kultur wchodzą ze sobą w ciągły i bezpośredni kontakt, co powoduje późniejsze zmiany w oryginalnych wzorcach zachowań tych grup (Berry 2003: 17-37, Kim, Abreu 2001: 394-424). W latach późniejszych J.W. Berry, rozwijając badania nad akulturacją, opracował jej teoretyczny model, w którym wyróżnił strategie, jakie mogą przyjąć przedstawiciele kultury przyjmującej (zwanej też kulturą dominującą lub kulturą mainstream) oraz ludność napływowa. Wśród możliwych strategii akul-

Marzena Karwowska — dr hab., Zakład Literatury Polskiej XX i XXI wieku, Instytut Filologii Polskiej i Logopedii, Wydział Filologiczny, Uniwersytet Łódzki, ul. Pomorska 171/173, 90-236 Łódź; e-mail: marzenakarwowska@poczta.onet.pl

1 Termin akulturacja pojawił się w języku angielskim już w wieku XIX (Sam 2006: 11-27). 
turacyjnych gospodarzy wyróżnił: multikulturalizm ${ }^{2}$, dekulturację̧, melting pot $^{4}$ lub pressure cooker ${ }^{5}$, segregację․ Migranci, zdaniem Berry'ego, mogą przyjąć jedną z czterech strategii: separację , integrację $^{8}$, asymilację ${ }^{9}$ marginalizację ${ }^{10}$ (Berry 2003, 2006). Jako najkorzystniejsza strategia akulturacji wskazana została integracja, zmierzająca do powstania tożsamości dwukulturowej (Berry 2006). Idea tożsamości kulturowej w Europie Zachodniej stała się przedmiotem zainteresowania Johanna Gottfrieda Herdera już w wieku XVIII, według którego każda kultura ma charakter homogeniczny i narodowy. Żadne próby indywidualne czy też zbiorowe o charakterze akulturacyjnym nie są w stanie tego monolitu kultury naruszyć (Herder 1966), zaś wszelkie przejawy kontaktu międzykulturowego nazywa Herder zaledwie „zderzaniem się kultur” (Herder 1967: 45) ${ }^{11}$. Polemikę z tą paradygmatyczną dla wieku XIX i XX wizją kultury podjął Wolfgang Welsch, który zaproponował własną koncepcję transkulturowości w epoce globalizacji. Zdaniem Welscha kultury tradycyjne nie mają charakteru monolitycznego, przeciwnie, posiadają znamiona kultur mieszanych, a w perspektywie diachronicznej wszelkie ruchy artystyczne w Europie, uwikłane w sieć wzajemnych oddziaływań i zależności, zawsze w istocie swej były transkulturowe. Herderowska teoria kultury jest według Welscha już nieaktualna, nie objaśnia bowiem zjawisk nam współczesnych — w epoce globalizacji „transkulturowość istnieje nie tylko na makropoziomie całych społeczności, ale sięga mikropoziomu tożsamości indywidualnej" (Welsch 2004: 34). Badacz stawia fundamentalne dla zjawiska akulturacji pytanie: jakie elementy kulturowe odpowiadają za uformowanie tożsamości kulturowej jednostki? Uwarunkowania takie odnajduje w zjawisku konwergencji kultur $^{12}$, które nazywa „transkulturowym wymieszaniem” (Welsch 2004: 43).

${ }^{2}$ Próba włączenia ludności napływowej w krąg kultury dominującej, z jednoczesnym umożliwieniem zachowania jej własnej tożsamości.

${ }^{3}$ Strategia utrudniająca asymilację migrantów z nową kulturą oraz uniemożliwiająca zachowanie ich własnej tożsamości.

${ }^{4}$ Melting pot ('kociołek') — przedstawiciele kultury dominującej stwarzają migrantom warunki dogodne do asymilacji.

${ }_{5}$ Pressure cooker ('szybkowar') — przedstawiciele kultury mainstream oczekują od migrantów szybkiej asymilacji i porzucenia kultury pochodzenia.

${ }^{6}$ Uniemożliwienie wejścia migrantom w obręb kultury gospodarzy przy jednoczesnym przyzwoleniu na kultywowanie własnych tradycji.

7 Zachowanie własnej tożsamości przy całkowitym odrzuceniu kultury mainstream.

${ }^{8}$ Zachowanie własnej kultury przy jednoczesnym przejmowaniu elementów kultury gospodarzy.

9 Porzucenie własnej kultury i utożsamienie się z kulturą mainstream.

${ }^{10}$ Brak poczucia przynależności zarówno do kultury rodzimej, jak i nowej kultury.

${ }^{11}$ Cyt. za: Estetyka transkulturowa 2004: 33.

12 Welsch przywołuje na poparcie swojej tezy słowa Amy Gutmann: „Ludzkie tożsamości, a dotyczy to nie tylko zachodnich intelektualistów czy elit, zostały ukształtowane przez więcej niż jedną kulturę. Nie tylko społeczności, ale i ludzie są wielokulturowi” (Gutmann 1993: 183). 
Zjawisko to jest konsekwencją faktu, że style artystyczne, modele filozoficzne, estetyczne i kulturowe koegzystowały przez wieki historii: „ludzie przyzwyczajeni do korzystania z kilku modeli, nie boją się różnorodności, nie muszą przyswajać obcej mentalności, by zaakceptować współczesny pluralizm" (Welsch 2004: 43). Jednostkowa tożsamość transkulturowa jest przejawem naszej „obecności w świecie" (Welsch 2004: 38). Zanurzenie człowieka w tyglu wielokulturowym posiada walor epistemiczny. Heterogeniczne teksty kultury w epoce globalizacji niosą na poziomie doświadczenia podmiotowego obietnicę poznania, której człowiek współczesny nie możemy zignorować:

Zwabieni w ten sposób zbliżamy się do nich, obserwujemy je uważniej, badamy intensywniej. Znaczy to, że uznajemy je — niezależnie od dystansu czasu i przestrze$\mathrm{ni}$ - za aktualne wyzwania zawierające potencjał uczynienia nas bardziej czułymi, otwartymi na sprawy dotąd niezauważane, bardziej świadomymi, bardziej ludzkimi. Nie zamykamy ich więc w ramach historii, a raczej czujemy lub oczekujemy, że sami zostaniemy z ich pomocą uwolnieni od ograniczeń, uzyskując szerszy, bogatszy obraz świata, samych siebie. (Welsch 2004: 38)

Koncepcja podmiotowej tożsamości transkulturowej Wolfgang Welscha stanowi ważny zwrot $\mathrm{w}$ badaniach nad zjawiskiem akulturacji, które jako przedmiot zainteresowania psychologów, antropologów, socjologów, filozofów kultury analizowane bywa zazwyczaj na poziomie grupowym i otwiera drogę do przeniesienie tych badań na poziom twórczego doświadczenia jednostkowego, skonkretyzowanego w tekstach literackich.

Celem artykułu będzie zatem próba przyjrzenia się obrazowi akulturacji utrwalonemu w Tarocie paryskim Manueli Gretkowskiej ${ }^{13}$, a przedmiot zainteresowania stanowić będą artystyczne strategie wyrażenia omawianego fenomenu.

Gretkowska nazywana bywa skandalistką (Hurnik 2016: 135-151), prowokatorką (Krassowski 1996: 12), gorszycielką ${ }^{14}$, a jej proza pojawia się w kontekście takich zjawisk jak pornografia, literacka szmira (Lengren 1995: 112-114, Wiedemann 1993: 93-95, Jarosińska 1993: 49-50) ${ }^{15}$, tandeta, kicz

13 Tarot paryski został wydany po raz pierwszy w roku 1993 przez krakowską Oficynę Literacką. Wszystkie cytaty w artykule pochodzą z wydania Gretkowska 1999.

${ }^{14}$ Zdaniem Piotra Śliwińskiego w Polsce dominuje ciągle model kobiecości ugruntowany przez socrealizm: kobiety powściągliwej, nie oczekującej wiele od życia, natomiast Gretkowska „wchodzi w nie obsadzoną rolę prowokatorki, gorszycielki, kobiety ekscentrycznej i wolnej. Rolę feministyczno-ironiczną. Od dziesięcioleci nikt właściwie tej roli nie usiłował grać." (Czapliński, Śliwiński 1999: 216).

${ }^{15}$ D. Nowacki nazywa pisarstwo Gretkowskiej „lombardem kiczu” (Nowacki 1994: 60), sama Gretkowska nazywa często swoje powieści harlequinami dla intelektualistów. 
(Miszczak 2001: 145-189; 1998: 135-153) ${ }^{16}$, ale też podmiotowa nietożsamość (Czapliński 1995), desakralizacja narodowych mitów (Czyżak 2003: 253). Pisarka, wywodząca się z kręgu „bruLionu” (Klejnocki, Sosnowski 1996; Dunin Wąsowicz, Varga 1995) ${ }^{17}$ w roku 1988 wyjeżdża do Francji, gdzie studiuje antropologię w École des hautes études en sciences sociales. W roku 1991 wydaje, rekomendowaną przez Czesława Miłosza, swoją pierwszą powieść My zdies' emigranty (1991), rodzaj quasi-traktatu antropologicznego, w który winkrustowany został zapis doświadczeń emigracyjnych pokolenia Polaków urodzonych w latach sześćdziesiątych. Do wątków tych powraca Gretkowska i rozwija je już w formie artystycznej w powieści Tarot paryski z roku 1993.

Problematyka akulturacyjna w strukturze powieści przypomina solenoid, autorka powraca do niej wielokrotnie na różnych poziomach organizacji tekstu. Pierwszym z takich poziomów jest multikulturowość bohaterów. Gretkowska zaludnia swoją powieść reprezentantami rożnych narodowości, których umieszcza w zamkniętej przestrzeni paryskiej kamienicy. Dla Charlotty, Polki z pochodzenia, jej męża Xaviera — „Francuza z Francuzów” (Gretkowska 1999: 50) oraz ich lokatorów: filozofa z Polski - Michała i szwajcarskiego stypendysty Thomasa owo zamknięte orbis interior, symbolizujące w sposób aż nazbyt oczywisty cały wielokulturowy Paryż, ma charakter ambiwalentny, raz jest przestrzenią izolacji, innym razem pretekstem do tego, aby „być razem” (Gretkowska 1999: 68).

Akcję swojej powieści umieszcza Gretkowska na Montmartre, w dzielnicy stanowiącej stolicę wielonarodowej cyganerii. Konstruując chronotop Gretkowska dzieli przestrzeń na szereg obszarów ograniczonych ścianami i zamkniętych drzwiami, oprócz mieszkania-pracowni Xaviera na Montmartre są to paryskie kawiarnie. Jedną z nich jest słowiańska restauracyjka na rue Pavée, do której Charlotta zwabia często swoją francuską przyjaciółkę Gabrielę. Zamiast opisywać sytuację psychologiczną polskiego emigranta w Paryżu Gretkowska przewrotnie gra konwencją swój-obcy i wprowadza chwyt à rebours stawiając prowokacyjnie „Francuzkę z Francuza” w sytuacji etrangera:

Uwielbiam Cię w tej knajpie, bo nie rozumiesz ani słowa. Możesz zamówić herbatę i jesteś bezradna, słysząc, jak kelnerka rozmawia po polsku, rosyjsku. Chcę żebyś chociaż tutaj była mniej u siebie. (Gretkowska 1999: 34)

W restauracji na rue Pavée transfer kulturowy nie zachodzi: dla Gabrieli Polacy spotykający się w kawiarni są niezrozumiali („Siedzicie w zatęchłej piwnicy, mówicie szeleszczącymi narzeczami" - Gretkowska 1999: 35). Przeciwnie, bohaterki

${ }^{16}$ Anna Mizerka interpretuje kicz w pisarstwie Gretkowskiej jako zabieg demitologizacyjny, szczególnie w odniesieniu do mitu kobieta-matka-Polka (Mizerka: 2006).

${ }^{17}$ Nazwa pisma bywa zapisywana trojako: „bruLion”, „brulion” lub „bRULION”. 
antagonizując kultury, których są reprezentantkami, podejmują kwestie tożsamościowe: według Charlotty Słowianie są dla innych nacji „nieprzetłumaczalni”, Gabriela kończy utarczkę słowną prośbą: „Pomówmy o Francuzach” (Gretkowska 1999: 35).

Druga z kawiarni, Le Mazet na Bulwarze Saint Germain, do której Gretkowska chętnie przenosi akcję swojej powieści, jest na zasadzie kontrastu przestrzenią w pełni multikulturową. W jej obrazowaniu pojawia się typowa dla powieści Gretkowskiej ambiwalencja waloryzacji. Widoczna jest ona we współwystępowaniu semantyki wspólnotowej (wśród galerii postaci koegzystujących w przyjacielskiej atmosferze w Le Mazet znajdziemy Bryana — amerykańskiego bluesmana, mnicha tybetańskiego w towarzystwie asystenta, Francuza „w powiewnej pomarańczowej szacie" (Gretkowska 1999: 102), chłopaka o południowej urodzie mówiącego po hiszpańsku) i obrazów rozpadu, schyłku tej wspólnoty (Thomas powołując się na etymologię arabską i hebrajską („mot, mat”) tłumaczy słowo Mazet jako „martwy” (Gretkowska 1999: 162).

Należałoby zadać sobie pytanie, jaką funkcję w utworze Gretkowskiej pełni konstrukcja przestrzeni jako obszaru zamknięcia, czy jest to symbol izolacji i samotności bohaterów, czy też przeciwnie synonim społecznej autarkii, samowystarczalności multikulturowej społeczności żyjącej w mieszkaniu Charlotty na Montmartre, i doskonale zorganizowanej, z własną ekonomią, językiem, organizacją dnia - Roland Barthes tego typu strukturę przestrzeni zamkniętej utożsamia ze szczęściem (Barthes 1996: 21).

Gretkowska nie daje tu jednoznacznych odpowiedzi, raczej nieustannie prowokuje, uchylając się od prostych diagnoz.

I tak, dla przeciwwagi, jednoznacznie pozytywnie waloryzuje multikulturowość Paryża w sekwencji scen obrazujących symbiozę kultur za pomocą symboli jednoczących, jakimi są paryski „zaułek-piramida” czy „koszerne beaujolais”: „przed Beaubourgiem, jak co dzień, Indianie w ponczach i melonikach śpiewają o kondorach. [...] Wspinając się po śliskim bruku, mijam siedzących w kucki Indian i stroma ulica staje się w rytm ich muzyki ścianą meksykańskiej piramidy" (Gretkowska 1999: 30). W mijanym bistro Charlotta wypija kieliszek beaujolais w towarzystwie przypadkowo poznanego lubawicza — członka ortodoksyjnej sekty żydowskiej. Podobny wymiar symboliczny ma postać „Monsieur Wonga” (Gretkowska 1999: 69), trwale wpisanego w pejzaż Paryża właściciela chińskiej restauracji w XIII dzielnicy, który wśród dymu kadzideł palących się przed figurką Buddy karmi swoich europejskich gości soją, przezroczystym makaronem i azjatyckimi konserwami z mięsa łabędzi czy też opis wystawy sklepowej oglądanej przez Charlottę w galerii handlowej: „Kilkanaście lalek i misiów przebranych w karnawałowe stroje weneckie tańczyło do muzyki Vivaldiego. - W tamtym 
roku były stroje mauretańskie — przypomniałam sobie świąteczne dekoracje Lafayette" (Gretkowska 1999: 132).

Ta coincidentia oppositorum bliska jest diagnozom kultury zaproponowanym przez André Malraux. Malraux, antropolog znany bardziej jako pisarz i minister kultury w rządzie de Gaulle'a, w książce L'Intemporel. La metamorphose des Dieux (Malraux 1976) zajmuje się kwestią intensywnego przenikania do kultury symbolicznej Europy fenomenów kultur, które nazywa egzotycznymi (azjatyckiej i afrykańskiej), określając ten proces mianem rewolucji kopernikańskiej. Taka transmisja kultur prowadzi do powstania ponadczasowego zjawiska estetycznego, rozpoczynającego światowy dialog kultur „poza historią”. Ten nieuchronny nowy fenomen, nazwany przez Malraux Sztuką Świata, zmieni jego zdaniem istotę kultury europejskiej. Dla Europejczyka oznacza to „zdjęcie katarakty z oczu” (Malraux 1985: 256), to jest przyjęcie nowej transkulturowej postawy estetycznej, opartej na metamorfozie widzenia: „Nasze widzenie poprzedza pilotujace spojrzenie, które proponuje sens, jaki mamy mu nadać" (Malraux 1985: 245) oraz na otwarciu się na zjawiska funkcjonujące poza momentem historycznym i paradygmatem geograficznym: „Metamorfoza, której ulega nasze obcowanie ze sztuką, jest jedyną formą życia dzieła sztuki w czasie” (Malraux 1985: 339).

W Tarocie paryskim Gretkowskiej owa wielokulturowość bywa jednak równie często waloryzowana negatywnie i utożsamiana z procesem degradacji kultury wysokiej starego kontynentu: „Żyjąc w Paryżu, można podróżować po rożnych światach, greckim, chińskim, włoskim, wystarczy przejść z jednej ulicy czy knajpy do drugiej. Egzotyczne światy, pstrokate, tandetne" (Gretkowska 1999: 134). Waloryzacja negatywna multikulturowości pojawia się też w konstrukcji głównej postaci powieściowej, wyobcowanie Charlotty i jej problemy z tożsamością zostały zaprezentowane za pomocą symboliki wina, które tutaj jawi się jako kod kulturowy czytelny tylko dla „Francuzów z Francuzów”:

— Thomas, do camemberta podaje się bordeaux, do każdego sera pasuje inne wino przekonywał Xavier. [...] — Charlotta do camemberta pije canelli. — Charlotta nie może być żadnym argumentem. Ona jest pół Polką, pół Francuzką, wszystko w niej jest pomieszane. (Gretkowska 1999: 134)

Brak umiejętności deszyfracji kodów kulturowych powoduje, że Charlotta jest postrzegana jako obca nawet przez konsjerżkę, Portugalkę:

- Bonsoir madame Azzolina, ładnie pachnie Pani sprzątanie.

- Bonsoir, bonsoir madame. Świąteczne sprzątanie.

- Do świąt jeszcze miesiąc.

— Jakby pani nie w Paryżu rodzona. Wystawiają choinki w Lafayette koło Opery, znaczy się czas sprzątać na Boże Narodzenie. (Gretkowska 1999: 89) 
Ważnym forum wypowiedzi na tematy akulturacyjne w Tarocie paryskim jest warstwa dialogowa powieści. Bohaterowie w swoich dyskusjach, pomimo różnic narodowościowych, wykorzystują intelektualne kody spójności kulturowej. Gretkowska proponuje na tym poziomie wędrówkę w czasie przez historię i teksty kultury, czytelne dla wszystkich multikulturowych bohaterów: od Orygenesa, Tertuliana, Kanta, Kartezjusza, Schopenhauera, Husserla, Dostojewskiego, Derridę, aż po egipskiego Horusa, kabałę i symbolikę Tarota. Jednocześnie jednak autorka wprowadza do narracji ironiczny dystans wobec akademickiej sofistyki bohaterów, widoczny w opisie ich pseudointelektualnych dyskusji. Manipulacja symboliką Tarota czy symboliką filmu Lyncha w celu uzasadnienia dowolnie postawionej tezy, to kolejne odsłony artystycznej prowokacji. Ma ona prowadzić do dekonstrukcji kodów spójności kulturowej, które, wydawałoby się, jest zdolny rozszyfrować człowiek pojmowany jako res cogitans, bez względu na przynależność narodową. Nawiązaniem aż nazbyt czytelnym do kartezjańskiej koncepcji antropologicznej, apoteozującej potęgę intelektu jako struktury transcendującej ograniczenia historyczno-geograficzne, jest przyniesiona z wykopalisk archeologicznych czaszka przechowywana w mieszkaniu Charlotty w lodówce zamiast jedzenia. Owa parodystyczna dekonstrukcja człowieka kartezjańskiego stanowi postmodernistyczną grę z tradycją. Za pomocą strategii ponowoczesnych Gretkowska rozbija spójność kodów kulturowych, dokonując ich desakralizacji (buty świętego w instalacji rzeźbiarskiej Xaviera śmierdzą, wino mszalne staje się tanim winem w kawiarni Le Mazet), inkrustuje w tkaninę europejskiej kultury wysokiej (akademickie rozmowy filozoficzne bohaterów, interpretacja przesłania obrazu Rembrandta Żdowska narzeczona, stypendium Fundacji Kultury) kicz, pornografię, pedofilię. Gretkowska nieustannie prowadzi z tekstami kultury intertekstualny dialog, scena defloracji dziesięcioletniej kuzynki przez Xaviera, wywołuje na dalszych kartach powieści asocjację z prozą Dostojewskiego i postacią Stawrogina oraz z aktami Modiglianiego, pijany Sasza peroruje na temat „antyhistorycznej kobiecości”, uwiecznionej na obrazie Rembrandta, tonąc spojrzeniem w silikonowym biuście Gabrieli („zostaną pięknie jędrne do końca życia pozagrobowego” — Gretkowska 1999: 92), czaszka przyniesiona przez Thomasa z wykopalisk archeologicznych kompromituje kulturową symbolikę dramatu szekspirowskiego:

Zastanawiamy się, gdzie ją położyć.

— Może na stole, obok świecy — zaproponował Szwajcar.

— Mein Gott, co za kicz — westchnął Xavier. (Gretkowska 1999: 72)

Gretkowska chętnie wykorzystuje w prezentacji poziomów akulturacji stereotypy narodowościowe: Charlotta co prawda nie zachowała polskiego imienia, ponieważ przeszła ryt inicjacyjny wejścia w obcą kulturę zapośredniczony 
przez małżeństwo z Xavierem ${ }^{18}$, ale pozostała ciągle dziewczyną ze słowiańskim, złotym warkoczem. Wielokulturowi mieszkańcy pracowni na Montmartre jedzą włoskie spaghetti, polski schabowy i rosół, francuskie foie gras, bagietkę i camembert popijając francuskim bordeaux lub włoskim canelli, a tym co ich jednoczy jest wspólny niedostatek, międzynarodowy język biedy, najdosadniej wyrażony w obrazie wspólnego poszukiwania na śmietnikach XVI dzielnicy sprzętów do mieszkania Charlotty. Ironia („Coraz rzadziej będziemy jedli — powiedziałam, tasując karty. To nie wróżba, po prostu kończy się forsa” — Gretkowska 1999: 61) i dystans to kolejna prowokacyjno-gorzka odsłona transferu kulturowego.

W Tarocie paryskim Gretkowska przekracza granice, podejmuje grę ze stereotypami, łamie tabu, desakralizuje mity. Desakralizuje romantyczny mit miłości małżeńskiej (zamiast niej proponuje czytelnikowi sceny seksu małżeńskiego $\mathrm{w}$ bramie ${ }^{19}$ czy polemikę z prokreacyjnym charakterem związku małżeńskiego para gejów z Londynu wręcza francuskim przyjaciołom kolczyki wykonane z martwych płodów), mit dziewictwa zastępuje incestem i pedofilią (dziesięcioletnia Odille przeżywa swoją inicjację seksualną z pijanym kuzynem).

Bohaterowie powieści Gretkowskiej na sposób Schelerowskii ${ }^{20}$ zacierają w swoim życiu granice między świętością i profanicznością — mit świętego Mikołaja zostaje wyparty przez hazard — homo religiosus ustępuje miejsca homo ludens:

Wuj przegrywa u Xaviera corocznie pięćset franków. Dawniej dawał swojemu ulubionemu bratankowi na Boże Narodzenie parę setek za pośrednictwem świętego Mikołaja. [...] Kiedy Xavier skończył szesnaście lat, świętego Mikołaja zastąpiła ruletka. (Gretkowska 1999: 122)

Xavier, dawny ministrant z Notre Dame, podczas przygotowanej przez Charlottę polskiej kolacji wigilijnej z udziałem stypendystki z Korei Południowej, kpiarsko desakralizuje zakorzenioną w tradycji symbolikę chrześcijańską:

Zjedliśmy dwanaście dań. Czang była bardzo wzruszona, jej pierwsze święta poza domem. Niemal z nabożeństwem nakładała sobie na talerz kawałki karpia, pierogi. Wstaliśmy od stołu po północy, Czang podziękowała za zaproszenie, ukłoniła się kilka razy. Zaczerwieniona z emocji [...] odważyła się cieniutkim głosem poprosić nas o jedno ździebełko siana spod obrusu — zawiezie je swojej rodzinie w Seulu. Oprawią

${ }^{18} \mathrm{~W}$ misteriach inicjacyjnych adept umierał symbolicznie, aby otrzymać nowe życie (co wiązało się często ze zmianą imienia) i zostać przyjętym przez wspólnotę (szerzej na ten temat, por. Vierne 2000).

19 „Na rue des Martyres nikogo nie zdziwi, że klęczę zasłonięta twoim rozpiętym płaszczem. Nocni przechodnie pomyślą z politowaniem, że nie stać nas na hotel. Karmię się tobą mój wielosmakowy kochanku. Masz dzisiaj smak czosnku i antybiotyków" - Gretkowska 1999: 70).

${ }^{20}$ Zdaniem Maxa Schelera żyjemy w epoce „zacierania się przeciwieństw” (Scheler 1987: 191-237). 
źdźbło w ramki za szkłem, siano ze żłobka Jezusa. Gabriela, chichocząc zasłoniła się puderniczką, niby poprawiała makijaż, Xavier wyskoczył z łóżka, capnął garść siana i wcisnął jej do ręki — Czang, bierz, dla całej parafii. (Gretkowska 1999: 125)

W podobnej funkcji demitologizacji i dekonstrukcji kulturowych symboli wprowadziła do swojej powieści Gretkowska postać kloszarda z metra paryskiego w roli współczesnej personifikacji Ducha Świąt: „Kloszard poobwieszany bombkami, z wyrysowaną gwiazdą na czole, owinięty złotym łańcuchem po czekoladkach zastępuje drogę w wąskich przejściach, prosząc o datki dla bożonarodzeniowej choinki" (Gretkowska 1999: 126).

W opisie sceny rozmowy Charlotty i Michała w kawiarni Gretkowska symultanicznie prowadzi dwa plany prezentacji: pierwszy z nich przedstawia dialog bohaterów na temat kontemplacji zakonników w klasztorze Cordes-sur-ciel, świętości modlitwy, scenę łamania chleba i zanurzania go w winie, drugi plan prezentacji buduje podstarzała Juliette Greco, kelnerka rozlewająca za kontuarem tanie beaujolais, wyślizgany drewniany stół oblepiony brudnymi filiżankami i talerzami pełnymi petów, sparaliżowany kloszard podnoszący w zębach szklankę i wysysający z niej resztki wina, „skrzypnięcie drzwi kibla popychanych przeciagiem, dyskretna odsłona popstrzonego klozetu, moment kontemplacji” (Gretkowska 1999: 137).

W konstrukcji epizodycznej postaci powieściowej, Michela, Gretkowska desakralizuje symbolikę lucyferyczną. Postmodernistyczna transformacja tego współczesnego wcielenia lucyferyzmu przybiera formę groteski, jedynymi przejawami infernalnych mocy Michela są pomalowane czarnym lakierem paznokcie i kolczyki wykonane z ludzkich płodów zanurzonych w żywicy. Gretkowska ośmiesza wszystkie lucyferyczne gesty i atrybuty swojego powieściowego bohatera, które stają się na kartach Tarota paryskiego zaledwie rekwizytami w kiczowatej teatralizacji życia — ciężar kolczyków deformuje uszy Michela, czarne paznokcie i srebrne pierścienie na palcach stanowią elementy popkulturowej stylizacji deathmetalowej.

Jaki zatem obraz akulturacji wyłania się ostatecznie z ponowoczesnego chaosu obrazów składających się na powieść Gretkowskiej?

Paryż pojmowany metonimicznie jest wielką metaforą strategii akulturacyjnej, która bliska jest multikulturalizmowi, przybysze jednak, pomimo okoliczności sprzyjających — zdawałoby się — asymilacji („Paryż jest pretekstem, żebyśmy byli razem” — Gretkowska 1999: 68), wpisują się swoimi postawami w schemat marginalizacji, wiodąc raczej życie „skazanych na Paryż”, (Gretkowska 1999: 126). Bohaterowie powieści Gretkowskiej poszukując własnej tożsamości kulturowej, doświadczają uczucia egzystencjalnej obcości, heideggerowskiego 
Geworfenheit. Thomas, szwajcarski doktorant o „wygasłych oczach”, jest w istocie „niedostępny”: „Niby jest z nami w każdy wieczór, opowiada zabawne historyjki, włóczy się z Michałem po muzeach i bibliotekach, zajmuje Xaviera obsesją mówienia o niczym, a tak naprawdę wcale z nami nie jest. Siedzi przy stole, jakby siedział w poczekalni dworcowej" (Gretkowska 1999: 91). Polski emigrant, Michał, swoją próbę asymilacji wieńczy samobójstwem w paryskim mieszkaniu Xaviera:

Posłuchaj — powie przed śmiercią Charlotcie — „Śmierć”, „śmierci”, najbliższe tym słowom jest „śmierdzi”, jeszcze nie zdążysz umrzeć, a już śmierdzisz. We francuskim jest poetyckie, dźwięczne la mort, brzmi niemal jak l'amour. Nie chcę umierać w języku polskim, moja ostatnia wola, je ne voudrais pas mourir dans la langue polonaise. (Gretkowska 1999: 136)

Ta ambiwalencja postaw widoczna na styku akulturacji i poszukiwania tożsamości indywidualnej oraz grupowej, narodowościowej bliska jest figurze mitycznej Persefony, która od momentu skosztowania owocu granatu wszędzie jest u siebie i jednocześnie nigdzie nie jest u siebie, jak Charlotta, pół Francuzka ze słowiańskim złotym warkoczem, niestosownie pijąca do camemberta słodkie canelli. Dlatego też Charlotta, zawieszona między próbą integracji i marginalizacją kulturową, w chwili rozpaczy komunikuje mężowi swój ból w języku przodków. Reakcja Xaviera tę marginalizację tylko pogłębia: „Prosisz, żebym się uspokoiła i mówiła po francusku, bo nic nie rozumiesz" (Gretkowska 1999: 70).

\section{BIBLIOGRAFIA}

Barthes Roland. 1996. Sades, Fourier, Loyola. Przeł. Renata Lis. Warszawa: KR.

Berry John W. 2006. Contexts of Acculturation. W: The Cambridge Handbook of Acculturation Psychology. Red. J.W. Berry, David L. Sam. Cambridge: Cambridge University Press. S. 27-43.

Berry John W. 2003. Conceptual Approches to Acculturation. W: Acculturation. Advances in Theory, Measurement and Applied Research. Red. Kevin M. Chun, Pamela B. Organista, Marin Washington: American Psychological Associacion. S. 17-37.

Czapliński Przemysław. Sztuka prozatorska Manueli Gretkowskiej. „Kresy” 1995, nr 8.

Czapliński Przemysław, Śliwiński Piotr. 1999. Kontrapunkt. Rozmowy o książkach. Poznań: Obserwator. S. 216.

Czyżak Agnieszka. „Polka” w szponach natury. „Poznańskie Studia Polonistyczne” 2003, nr 10. S. 253.

Dunin Wąsowicz Paweł, Varga Krzysztof. 1995. Parnas-Bis. Stownik literatury polskiej urodzonej po 1960 roku, Warszawa: Lampa i Iskra Boża. 
Herder Johann Gottfried. 1966. Outlines of a philosophy of the History of Man. New York: Bergman Publishers.

Herder Johann Gottfried. 1967. Auch eine Philosophie der Geschichte zur Bildung der Menschheit, Frankfurt/Main: Suhrkamp.

Gretkowska Manuela. 1999. Tarot paryski. Wyd. III, poprawione. Warszawa: W.A.B.

Gutmann Amy.1993. The Challenge of Multiculturalism in Political Ethics „Philosophy \&Public Affairs", 22, nr 3 (1993). S. 171-206.

Hurnik Janusz. 2016. Manuela Gretkowska: skandalistka czy mieszczka? W: Antropologia kultury mieszczańskiej. Red. Joanna Ławnikowska-Koper i Lucyna Rożek. Częstochowa: Akademia im. Jana Długosza. S. 135-151.

Jarosińska Izabela. Gdzie jest ten emigracyjny skowyt. Recenzja Tarota paryskiego. „Nowe Książki” 1993, nr 12. S. 49-50.

Kim B.S., Abreu J.M. 2001. Acculturation Measurement. Theory, Current Instruments, and Future Directions. W: Handbook of Multicultural Counseling. Red. J.G. Ponterotto, J.M. Casas, L.A. Suzuki, C.M. Alexander. London: SAGE Publications. S. 394-424.

Klejnocki Jarosław, Sosnowski Jerzy. 1996. Chwilowe zawieszenie broni. O twórczości tzw. pokolenia „bruLionu” (1986-1996), Warszawa: Sic!

Krassowski Maciej. Gretkowska jako prowokacja. „Wiadomości Kulturalne” 1996, nr 26. S. 12 .

Lengren Magda. Proza w btazeńskiej czapce. „Twórczość” 1995, nr 1. S. 112-114.

Malewska-Peyre Hanna. 2001. Swojskość i obcość. O akulturacji imigrantów w Polsce. Warszawa: Wydawnictwo Instytutu Psychologii PAN.

Malraux André. 1976. L'Intemporel. La metamorphose des Dieux. T. 3. Paris: Edition Gallimard.

Malraux André. 2000. Ponadczasowe. Przemiany bogów. Przeł. Jerzy Lisowski. T. 3. Warszawa: Krajowa Agencja Wydawnicza.

Miszczak Magdalena. Kicz i parodia w prozie Manueli Gretkowskiej. Czym jest; Jak jest; Po co jest. „Acta Universitatis Lodziensis. Folia Litteraria Polonica”, 2001, z. 2. S. 145-189.

Miszczak Magdalena. Manueli Gretkowskiej zabawy (z) kiczem. „Teksty Drugie” 1998, nr 6. S. 135-153.

Mizerka Anna. O publicznym wizerunku Manueli Gretkowskiej i estetyce kampu. „Podteksty” 2006, nr 1(3).

Nowacki Dariusz. Jeden Paryż i dwie techtaczki. „FA-art” 1994, nr 4. S. 60.

Floyd W. 2003. Critical History of the Aculturation Psychology of Assimilation, Separation, Integration, and Marginalization, „Review of General Psychology” 2003, nr 7(1). S. 3-37.

Sam David L. 2006. Acculturation: conceptual background and core components. W: The Cambridge Handbook of Acculturation Psychology. Red. John W. Berry, David L. Sam. Cambridge: Cambridge University Press. S. 11-27. 
Scheler Max. 1987. Pisma z antropologii filozoficznej $i$ teorii wiedzy. Przeł. Stanisław Czerniak i Adam Węgrzecki. Warszawa: Wydawnictwo Naukowe PWN.

Welsch Wolfgang. 2004. Tożsamość w epoce globalizacji - perspektywa transkulturowa. Przeł. z j. ang. Krystyna Wilkoszewska. W: Estetyka transkulturowa. Red. Krystyna Wilkoszewska, Kraków: Universitas. S. 31-43.

Wiedermann Adam. Tarot jest światem, a świat wariatem. „Czas Kultury”, 1993, nr 4. S. 93-95.

Wilkoszewska Krystyna, red. 2004. Estetyka transkulturowa. Kraków: Universitas.

Vierne Simone. 2000. Rite, roman, initiation, Grenoble: Presses Universitaires de Grenoble.

\title{
Marzena Karwowska
}

\section{IMAGES OF ACCULTURATION IN "THE PARISIAN TAROT"}

\author{
(summary)
}

The current state of research on acculturation indicates that this issue has gained a growing interest in recent years among researchers such as Rudmin, Berry, Kim, Abreu, Malewska-Peyre. In the 1930's, thanks to anthropologists such as Redfield, Linton and Herskovits, an understanding of the phenomenon of acculturation crystalized in the humanistic discourse. Already in the eighteenth century the idea of cultural identity in Western Europe interested Johann Gottfried Herder, who believed that every culture is homogeneous and national. A polemic with this vision of culture, which was paradigmatic for the nineteenth and twentieth century, was expounded by Wolfgang Welsch, who proposed his own concept of transculturality in the era of globalization. Wolfgang Welsch's concept of transcultural identity is an important turning point in the study of the phenomenon of acculturation, which, as a matter of interest to psychologists, anthropologists, sociologists and philosophers of culture, is usually analyzed at the group level and opens the way to transfer these studies to the level of creative individual experience, specified in literary texts.

The aim of the article is therefore an attempt to look at the image of acculturation fixed in the Parisian Tarot by Manuela Gretkowska, and the subject of interest are the artistic strategies for expressing this phenomenon.

\section{KEYWORS}

Manuela Gretkowska; Tarot paryski; acculturation 